\title{
Correction to: Assessment of potentially toxic elements in vegetables cultivated in urban and peri-urban sites in the Kurdistan region of Iraq and implications for human health
}

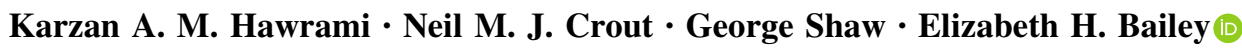

Published online: 16 February 2021

(C) Springer Nature B.V. 2021

Correction to: Environ Geochem Health (2020) 42:1359-1385 https://doi.org/10.1007/s10653-019-00426-z

In the original publication of the article, the affiliation of the first author.

"Karzan A. M. Hawrami” was incorrectly published as "Sulaymaniyah Polytechnic University, Technical Institute of Halabja, Zamaqi, Halabja, Iraq".
The correct affiliation is "Sulaimani Polytechnic University (SPU), Technical Institute of Halabja, Zamaqi, Halabja, Iraq".

Publisher's Note Springer Nature remains neutral with regard to jurisdictional claims in published maps and institutional affiliations.

The original article can be found online at https:// doi.org/10.1007/s10653-019-00426-z.

K. A. M. Hawrami · N. M. J. Crout .

G. Shaw · E. H. Bailey $(\bowtie)$

School of Biosciences, University of Nottingham, Sutton

Bonington Campus Loughborough,

Leicestershire LE12 5RD, UK

e-mail: Liz.Bailey@nottingham.ac.uk

K. A. M. Hawrami

Sulaimani Polytechnic University (SPU), Technical

Institute of Halabja, Zamaqi, Halabja, Iraq 